\title{
DIFFICULTIES AND BARRIERS IN THE EDUCATION OF DEAF AND HARD OF HEARING INDIVIDUALS IN THE ERA OF COVID-19: THE CASE OF GREECE - A VIEWPOINT ARTICLE
}

\author{
Constantinos N. Mantzikos ${ }^{1 i}$, \\ Christina S. Lappa ${ }^{2}$ \\ 'Special Education Teacher, \\ $1^{\text {st }}$ Special Kindergarten of Larissa, \\ Greece \\ ${ }^{2}$ Post Doc, PhD, \\ University of Thessaly, Volos, \\ Greece \\ Hellenic Open University, Patras, \\ Greece
}

\begin{abstract}
:
This article provides an analysis of the difficulties and barriers deaf and hard of hearing individuals face during the period of the COVID-19 pandemic. In a pandemic situation, apart from the economy, education is also largely affected. In the past few months, many disabled and non-disabled pupils and university students were taken by complete surprise by the immense changes in the education sector and mainly by the innovations introduced, especially in the lower education grades, which resulted in considerable implications, despite the positive response they received. In these trying times humanity is experiencing, the difficulties that deaf and hard of hearing individuals have to face were exacerbated, perpetuating their marginalisation.
\end{abstract}

Keywords: education; deaf and hard of hearing; COVID-19; difficulties; barriers; Greece; viewpoint

\section{Points of Interest}

- There is a lack of resources in Greek public schools.

- There are many obstacles in accessibility for deaf and hard of hearing individuals in primary, secondary and higher education.

- The review revealed that the majority of teachers hold positive attitudes toward inclusion of deaf and hard of hearing children, but they feel unprepared to teach them. Therefore, more in-service training is needed in order to teach effectively these children.

\footnotetext{
i Correspondence: email kmantzikos@gmail.com
} 
- The COVID-19 crisis affects numerous individuals around the world, including disabled people.

- The COVID-19 crisis affects the education of deaf and hard of hearing students in preschool, primary, secondary and higher education.

- The marginalisation and exclusion of this disabled group have been amplified to a much greater extent than previously.

- More research is needed in order to better understand the experiences of these people during the current crisis humanity is witnessing.

- In these difficult times, more inclusive practices are needed in order to meet the needs of deaf and hard of hearing students.

\section{Introduction}

Inclusive education is a timely issue that concerns many researchers both in Greece and abroad. It constitutes a new impetus for the development of today's school. In fact, it is an applied policy, a philosophy of pioneering change in its entire connotation. Ainscow (2005) defines inclusive education as a process whose main objective is the inclusion of all students with disabilities and/or special educational needs in school in order to have learning outcomes and conditions to further their social development. In practice, inclusion means teaching in heterogeneous classes in which students with varying individual needs exist (Takala, Pirttimaa, \& Törmänen, 2009). It is about the active presence, meaningful participation and acceptance of the student with disabilities in a classroom of general education (Humphrey \& Lewis, 2008). It assures a feeling of 'belonging' and the shared responsibility of teachers for all students in the school unit (Takala et al., 2009). Proper functioning of inclusion means accepting diversity and removing exclusion at all levels (social, economic, academic, racial, gender, etc.) (Slee, 2011), adapting teaching (pedagogical methods) and curriculum, teacher collaboration, and support from the headmaster/director of the school unit (Takala et al., 2009). It is, therefore, according to Stasinos (2016) "the design of a curriculum and an organisational strategy in mainstream schools that respond to the full spectrum of student diversity and diversity as a whole" (p.59).

In short, the term "inclusion" refers not only to the placement of a child with special educational needs in the regular school, but also to the conditions under which all children can be effectively educated (Angelides, Stylianou, \& Gibbs, 2006). Soulis (2008) correctly states that inclusion is not just a personal matter of special education teachers in the general school, thereby relieving the general education teacher of responsibility for its implementation. Inclusion can only be realised and achieved when all stakeholders are involved. For this reason, teachers are required to create learning environments that encourage the use of practices to empower these students. Teacher cooperation is essential. Hughes and Murawski (2001) consider that collaboration means interaction between at least two teachers with different specialisations and includes dialogue, 
planning, shared and creative decision making as well as feedback aimed at providing appropriate services to students.

\section{The Greek context}

In Greece, there are a number of laws and presidential decrees were introduced to determine how to educate students with disabilities and/or special educational needs in special and general education classrooms. Article 1 of the first Legislative act 1143/1981 defines the student population, the intentions of the special education provided and the principles for the establishment of the study structures: "The purpose of this law is to provide special education and specialised vocational training to persons deviating from what is considered normal, the introduction of social measures and their corresponding integration into the social life and professional productivity through the implementation of specific educational programmes in conjunction with medical and other social issues."

In the mid-1980s, Law 1566/1985 was introduced, which continued more or less in the same manner as the aforementioned law. In 2000, Law 2817 introduces the operation of KEDDY Yi (Greek Public Diagnostic and Assessment Centres for the Support of Special Educational Needs) at the headquarters of each prefecture. In addition, students with disabilities and/or special educational needs can attend a general education class through the parallel support or in a special organised and staffed inclusive class, which function in the mainstream education provided by a special education teacher. The special education teacher may help these students in some or all courses depending on their needs (Sarris, Riga, \& Zaragas, 2018). Finally, in the same line as the previous law, the Legislative Act on Special Education 3699/2008 (Nteropoulou-Nterou, 2012).

Based on this law, students with disabilities and/or special educational needs may attend general education classes (Parallel Support or Resource room) based on the judgement and written declaration of the KESY. Moreover, for the provision of the general education classes a basic criterion is considered the type as well as the degree of disability of the student (Drakotou \& Zoniou-Sideri, 2016; Kontoleon, \& NteropoulouNterou, 2013; Lampadari \& Gkaravelas, 2018; Novakos, 2018; Tentomas, 2017).

In most cases deaf and hard of hearing children attend in general education classes with the support of a special education teacher or teacher for the deaf. Some deaf and hard of hearing children due to their severe difficulties or other concomitant impairments are enrolled in special schools for the deaf and hard of hearing pupils.

On the other hand, at the higher education level, these individuals are allowed by Law (Article 35 of the Legislative act 3794/2009-FEK 156/A') to attend classes at Greek universities. They sit for entrance examinations instead of PanHellenic examinations. Of course, they have the right to participate in the PanHellenic examinations with proper preparation for this procedure.

ii The name has changed with a new Law 4547/2018: Educational and Counseling Support Centers (K.E.S.Y). 


\subsection{A short review on inclusive and special education of deaf and hard of hearing children}

In recent years very little research has been done on teachers' attitudes towards the inclusion of deaf and hard of hearing children in general and special education schools. However, the findings of the research that has been done appear to be contradictory.

More specifically, Kiriungi et al. (2014) examined the attitudes of 400 teachers in public primary education from the central region of Kenya. These teachers had positive attitudes towards the inclusion of deaf and hard of hearing pupils, but they felt unprepared to teach these children. Also, there was a statistical difference in their attitudes depending on the gender of the teachers. Men teachers were more positive than women towards teaching this group.

In another study, Mapolisa and Tshabalala (2013) examined the attitudes of twenty teachers from a primary school in Zimbabwe. The results of their study revealed that deaf and hard of hearing children faced many problems in general education settings. An important finding is that the majority of general education teachers did not have the proper expertise needed and did not have sufficient resources to manage deaf students. In their study, the researchers suggest in-service training courses on how to effectively manage the hard of hearing students in general education classes.

In another study, Sari (2007) revealed that the attitudes of teachers had become more positive after an in-service training course. In particular, their attitudes concerning classroom management changed.

Alasim and Paul (2018) examined the attitudes of general education teachers towards the inclusion of deaf and hard of hearing children in primary schools in Saudi Arabia. The researchers found that teachers held neutral attitudes on the inclusion of these children. An important finding is that these teachers had not worked with hard of hearing children. Women teachers had more positive attitudes towards the inclusion of these pupils.

In a study from Tehran, Parhoon, Movallali, Hassanzadeh and Moravej (2014) found that teachers held positive attitudes towards implementation of an inclusive education system for hard of hearing children. There was a significant difference in attitudes, which varied depending on the teaching experience, gender and educational level. The results also showed that most teachers were receptive to the inclusion of hearing-impaired students in their classrooms.

In a comparative study from Greece, Lampropoulou and Padeliadu (1997) revealed that the attitudes of teachers differed depending on their field of work. More specifically, teachers of the deaf held more positive attitudes than the other two groups of teachers. But they held negative attitudes towards inclusion of these pupils. The researchers pointed out that the attitude of general and special education teachers towards inclusion can be explained on the basis of their attitude towards disability, but for teachers of deaf students, this attitude was not related to the attitude towards disabled individuals. 
In another study from Greece, Vakrou and Dimakos (2016) found that the two groups of special education teachers from general and special schools were in favour of segregated education, special schools or Resource rooms for deaf and hard of hearing children. Also, the researchers revealed that the two groups showed different attitudes depending on the benefits of attendance at these units. In particular, the special education teachers were of the opinion that at special schools for the deaf, teachers know the educational needs of the deaf and hard of hearing students better and that these students gain significant benefits and form their identity by attending the special school for the deaf, while the teachers of the deaf held the view that deaf and hard of hearing students reap significant benefits from their inclusion in the Resource room. Regarding the adequacy of support structures for the effective teaching of deaf and hard of hearing students, the majority of the two groups of teachers considered that support structures were not sufficient. Finally, a small percentage of special education teachers (9.5\%) considered that they have the necessary knowledge and the necessary training. On the contrary, teachers of the deaf were of the opinion that they have the necessary knowledge and the necessary training to meet the needs of deaf and hard of hearing students.

In Ottawa, Canada, Ericks-Brophy and Whittingham (2013) examined the attitudes of 63 teachers. They found that these teachers held positive attitudes towards the inclusion of hard of hearing children, while at the same time they had confidence in their teaching abilities and had knowledge about the effect of hearing loss on language and learning. It also appeared that the teacher education courses that the teachers had attended had not sufficiently prepared them for effective teaching of these students. Researchers point to the need to increase the emphasis on the different educational needs of hearing-impaired students in teacher education courses, as well as to provide appropriate support to both teachers and students, with a view to successful inclusion.

\subsection{The accessibility of disabled individuals in Primary, Secondary and Higher Education}

In the lower grades, Vlachou and Papananou (2015) conducted research about the accessibility of disabled children in the school environment. They revealed that the participants remained in schools that do not cover their needs because of the indifferent attitude of teachers, or they did not have training to cover those needs. School facilities were inaccessible to them, and there was no differentiated educational material for that category of individuals. Participants with physical disabilities found that their autonomy and safety were severely hampered by the architectural design of the school facilities, while those with sensory difficulties were mainly affected by the inaccessible curriculum. Participants described the Greek education system as rigid and particularly inaccessible to disabled learners (Vlachou and Papananou, 2015).

In a study by Ackah-Jnr and Danso (2018) it was found that $61 \%$ of teachers were of the opinion that the physical environment of schools was considered less accessible to children with physical, neuromotor or sensory disabilities and that these children generally face daily difficulties in school life. Similarly, research by Hankebo (2018) 
showed that in Ethiopia school education and training activities were not accessible to disabled children. In their review, Drame and Kamphoff (2014) showed that in order to increase the effectiveness of inclusive education in Senegal, the country should increase the access of disabled children to school education through providing physical access to the schools.

Meanwhile, the results of a survey conducted in Cyprus by Helen Phtiaka (2008) were mirrored in Greece. In particular, Phtiaka showed that the participants expressed strong criticism about the lack of educational materials in some schools. Also, the lack of appropriate educational material is found mainly in general education classes. According to the researcher, the design of these classes does not give the impression that disabled children are included in the general school or that they are a priority. This is because teachers do not take the needs of these students into account, in order to make a proper arrangement of the classroom.

A similar view can be found in the study by Mavropalias, Alevriadou and Rachanioti (2019), who mentioned that general education schools should be equipped with the right materials and resources.

At the higher education level, most of the international studies mentioned that there is a lack of support for lecturers, and that universities remained inaccessible. Specifically, in a study by Fuller, Bradley and Healey (2004) it was found that some students had problems when teachers spoke too fast or removed visual material, such as slides, before they could assimilate the content, while other students complained because teachers kept talking while turning their heads in the opposite direction of the audience. Many students had significant difficulty listening or watching while taking notes, leaving them in a dilemma as to where to focus and often ending up with incomplete notes. Students felt that providing ready-made notes or additional support material was not always enough to overcome these difficulties and, sometimes, might even be an obstacle. In a similar study by Fuller, Healey, Bradley and Hall (2004), it was found that there have been cases where teachers have not made changes based on the student's disability, perhaps because they were unaware of it so that they can act flexibly and comprehensively. However, there were cases in which the staff did not show any willingness to help, even though they were aware of the disability and the needs of the disabled student.

Moswela and Mukhopadhyay (2011) found that the university failed to provide adequate educational support to disabled students. There was a general lack of educational materials and infrastructure, as well as negative attitudes towards these people. While disabled students were naturally present at the university, the data revealed that access to the curriculum and facilities remained a complex issue and were not tailored for them. Some teachers were reluctant to meet the learning needs of disabled students.

Vlachou and Papananou (2018) found that almost all participants stated that they had to struggle with the inability of the university to meet their needs and ensure access at all levels. Specifically, the interviews conducted by the researchers showed that in the 
university area there are inappropriate elevators and stairs and inadequate lighting, lack of a ramp and toilets inaccessible to wheelchairs, as well as poor acoustics in the classrooms. The participants were of the opinion that the teachers did not show real interest and did not have the knowledge about how to offer appropriate support. In fact, some of the main obstacles mentioned by the participants were the lack of substantial support and the lack of any differentiation, as well as the reluctance to make any modifications.

The research of Sakkou and Nteropoulou-Nterou (2016) showed that the academic participation of deaf and hard of hearing students often becomes difficult, and this is mainly due to the lack of sign language interpreters and the undifferentiated teaching, learning and assessment practices followed by lecturers.

In Spain, Moriña and Orozco (2020) conducted interviews with 119 faculty members from 10 universities. Their study showed that barriers related to physical organisation and building structure were the ones that were reported as the most obvious and most common. According to the participants, the physical organisation of the university is not designed to serve all students, just some of them. The second most common obstacle mentioned by teaching staff is that disabled students have to overcome multiple obstacles, due to the lack of knowledge and training of the staff.

\section{COVID-19 and statistics for school closure}

In December 2019, an outbreak of COVID-19 occurred in Wuhan City, Hubei Province in Central China. On March 11, 2020 the World Health Organisation declared the outbreak as a pandemic. Nowadays, COVID-19 is a pandemic that knows no borders, socioeconomic status, age, colour, gender, disability and religion. It is a novel virus that we are still trying to understand in various scientific ways (medical, sociological, anthropological, etc.). It is estimated that approximately more than 30 million people around the world have been infected by COVID-19 (see also at: https://www.worldometers.info/coronavirus/).

In Greece, it is estimated that approximately more than 14.000 people have been infected by COVID-19. More than 8.000 people have been recovered by this novel virus (see also at: https://www.worldometers.info/coronavirus/country/greece/).

On the other hand, in their article Viner and his colleagues mention official statistics about the worldwide school closure in the early stages of the pandemic. Specifically, they mention that: "[a few days later], on March 18, 2020, the UN Educational, Scientific and Cultural Organisation estimated that 107 countries had implemented national school closures, affecting 862 million children and young people, roughly half the global student population" (Viner et al., 2020, p. 1). This closure of schools worldwide has resulted in numerous problems for the psychological, social and learning development of many children, including disabled children. Of course, children from low-income families were more likely to be affected by this situation than children from high-income families (Edmunds, 2020). 


\subsection{The case of Greece}

The measures adopted by the Greek government during the pandemic include remote teaching for teachers/lecturers and distance learning for all pupils/university students. Based on the official data published on the Greek Ministry of Education website (2020), during this unprecedented situation, there was a broad response to implementing online education. More specifically, in primary and secondary education, with regard to synchronous learning, data show that in total 9,462,802 student sessions were carried out in digital classes, 766,458 student sessions were conducted in digital classes per day, 112,872 teachers created their personal digital class, 532,251 digital classes were created in total, 40,957 digital classes were created per day and 36,091,106 minutes of synchronous distance learning were completed. In asynchronous education, 744,973 student sessions were conducted on the e-class platform and 369,531 student sessions on the e-me platform, while 115,618 teacher sessions were conducted on the e-class platform and 75,259 teacher sessions on the e-me platform. In total, more than 1,099,421 pupils and 193,062 teachers have registered in the Greek School Network. Regarding the lessons established and implemented by the Greek Ministry of Education in collaboration with the Education Policy Institute and the Hellenic Broadcasting Corporation (ERT) during April, 145,000 (51,2\%) children aged 4-14 years old watched the educational TV programme daily. According to official data, in post-secondary and higher education, 96.3\% of the classes in public Institutes of Vocational Training that previously required physical presence have already been integrated in asynchronous distance learning. At universities, $96.35 \%$ of bachelor courses are taught through synchronous distance learningiii.

Furthermore, one very good step taken by the Greek government was that it has given priority to low-income families, unemployed parents, single-parent families, families with three children, large families, orphaned children, and disabled children. Also, technological equipment (laptops and tablets) was distributed based on the number of students and schools that really needed it. The tablets and laptops were purchased using donations of $€ 3,125,000$ (CEDEFOP, 2020) made by various companies (Ministry of Education, 2020).

Nevertheless, it is worth pointing out that, according to Papazoglou (2020), "distance learning in all education grades is no panacea, as it gives rise to a number of pedagogical and social issues" (par.3). For instance, many deaf and hard of hearing children may face many difficulties during distance learning courses. During real-time lessons using video conferencing many technical issues may arise and, most importantly, there has been no provision for real-time transcription and subtitling of what the teacher says on camera. This is an important obstacle for deaf and hard of hearing individuals and individuals with severe hearing impairment who have to rely on lip reading. What is more, there is no targeted feedback when they need it. The material provided is mostly standardised

\footnotetext{
iii For the difference between Synchronous and Asynchronous learning, you can see at: Lawless, C. (2020). Synchronous vs Asynchronous Learning: Which is Right for Your Learners? LearnUpon.com (Available online at: https://cutt.ly/zfjth0F).
} 
and does not stimulate their curiosity and interest, hindering their effective engagement. In fact, the interventions implemented though this channel are not structured in a way that can deliver the desired results. Their effect is only superficial. Furthermore, there is a lack of collaborative teaching which could deliver multiple benefits for deaf and hard of hearing individuals, including social, cognitive benefits, etc. The feelings of loneliness and isolation may increase even further (e.g., Khalil \& Ebner, 2014). Also, there have yet been no appropriate modifications and adaptations to the teaching material. Differentiated instruction is not applied either.

All the above also applies for lessons conducted via educational TV. Most importantly, it seemed that on educational TV programmes, lessons were not conducted using approaches that would benefit both disabled and non-disabled pupils, and the instructors who were conducting the lessons were not aware of the pupils' profiles, for example of whether they had a disability, of their level of understanding of Greek (pupils from countries other than Greece), learning level, etc. The lessons provided via educational TV were standardised. The lack of meaningful feedback is also important. Educational TV was just aimed to cover the curriculum and nurture the same attitudes as at schools before the COVID-19 pandemic. In other words, educational TV did not promote meaningful learning. We could go so far as to say that educational TV seems to promote certain ideas and goals aimed at fostering pupils' ability to be obedient towards the current system (e.g., Apple, 2016). In addition, by teaching the same content in the exact same way on educational TV, marginalisation and exclusion of certain pupils is amplified. Educational TV supports the idea of homogeneity, completely ignoring the elements of heterogeneity that are inherent in the pupil population.

Furthermore, distance learning was mostly intended for non-disabled pupils as is evident from the fact there was not a single lesson designed for deaf and hard of hearing pupils who attend special education schools. Despite their inalienable right to have access to information, they were left out of distance learning on the preconception that they constitute a difficult to manage population that requires more specialised educational approaches (Liasidou \& Symeou, 2016). It is no surprise that distance learning, as it was implemented, followed a segregated education approach, and that, during this tough period, the learning level these pupils had managed to reach before the COVID-19 crisis dropped substantially, and learning gaps arose (e.g., Levinson, Cevik, Lipsitch, 2020). The Greek Ministry of Education seems to have taken into consideration solely what is implemented at homogeneous schools, that is general education schools, that are only in theory inclusive. Thus, as Liasidou and Symeou (2016) point out, through the international literature, that "the education of these students is framed within a special education framework while ignoring the ways in which the concept of special educational needs [are] to a significant extent the result of the inadequate general educational system that fails to cater to learner diversity" (p. 10).

As for teachers, their communication and cooperation were interrupted because they acted as individuals rather than as part of a team. As a result, disabled pupils are further marginalised and, possibly, stigmatised, and many aspects of their development 
are negatively affected. Of course, this novel situation has affected parent-teacher collaboration. Many parents had increased levels of anxiety because they were not ready for this situation. Their anxiety was due to the fact that they had to address the needs of their child to a much larger extent than previously. We could say that, in this case, collaboration between the two sides became more complicated. It is a fact that the special education teacher's role in this collaboration is neither useful nor efficient because the technology does not ensure effective communication with the parents of these children. Also, communication was based on the exchange of standard material via e-mail or sometimes the two sides communicated through phone calls or video calls for a few minutes only. Some parents indicated they were not very satisfied with their collaboration with the special education teacher. Ineffective collaboration between parents and teachers may affect the learning and socio-emotional development of their deaf and hard of hearing child.

With the lifting of the measures and the opening of schools on June 1st, deaf and hard of hearing children faced two important barriers: face masks and the 1-metre social distancing rule. General and special education teachers are afraid about the transmission of COVID-19 within schools. They did not want to put themselves and these children in danger. However, face masks may impede speechreading and may make teachers' voices not very clear. This also applies to the 1-metre social distancing rule within the classroom. In this case, teachers could use written communication or a speech-to-text system or Greek Sign Language or any other teaching material in their lessons. However, it is important to mention that Greek public schools have experienced spending cuts on teaching materials. In his article Kavadias (2019) provides statistical data about the spending cuts faced by Greek public schools. "Public spending on education is among the lowest in the European Union, accounting for just 3.9\% of GDP. The largest decrease (25.8\%) was in "intermediate consumption", i.e. teaching materials, heating and electricity. This was followed by "gross fixed capital investments" (-20.4\%), which includes investments in computers, buildings, etc. Kavadias also states that "in 2019 the European Council addressed a special recommendation to Greece in which it called on it to invest in education and skills" (p.7). We could say that reducing spending on education leads disabled students to feel a sense of isolation and this has huge consequences for their mental health (Oliver, 2009).

Apart from primary and secondary education, multiple problems have been identified in higher education as well. In this field, the difficulties that existed before this crisis were intensified even more. The difficulties of this period further increased the marginalisation of deaf and hard of hearing individuals from education. The obstacles at this education grade are the same with those at lower education grades, especially for deaf and hard of hearing individuals. Teaching deaf and hard of hearing students who know sign language by using simultaneous interpreting or simultaneous subtitling seems quite unrealistic. It is not enough for students to be able to see the Power Point slides for a particular lesson. Lecturers do not just stick to the slides, they usually elaborate on them and say more things, which the deaf and hard of hearing students may not be able to hear due to their severe hearing impairment. Of course, in most cases, there is no possibility 
for speechreading because lecturers speech quickly or they cover their mouth with their hand. The speechreading is very important for their accessibility in the lesson. Moreover, again the lessons are carried out in a completely standardised form, which excludes deaf and hard of hearing students. It seems that lecturers do not have the time required to take meaningful steps that will help these students to actively participate and show real interest for the lesson. It could be argued that "the sudden switch to online teaching has uncovered even more the 'cracks in the curriculum'" (Barkas et al., 2020, p.2). This has led to an increase in the stress of this group of individuals (Kapasia et al., 2020). Due to the lack of support and understanding of these students' needs by the lecturers, the likelihood of them dropping out of university has increased (e.g., Liasidou, 2014).

Historically, in higher education it has not been possible to implement strategies and methods that embrace heterogeneity to a great extent. Some strategies and methods are partially effective for the heterogeneous student population, but these alone are not sufficient, due to the fact that the attitudes adopted and promoted at this education level are aimed at benefiting students only during their working life. But what happens when students graduate and the knowledge, they have acquired is useless to them? What happens when students start working and have to deal with learning gaps? What happened to the students' true interest for learning? The answer to these questions lies in the shortcomings of the practices that have been implemented all these years and are still implemented during the current times humanity is witnessing.

Pavlidis (2019) quite correctly points out that "the teaching of scientific knowledge in universities cannot be effective if it is not creative; if it is not distinguished by originality, penetrating insights, and well-rounded analysis; if it does not create an environment that promotes mental introspection and critical reflection. And because of these shortcomings, there is clear alienation between lecturers and students" (p.9).

\subsection{Implications for practice and directions for future research}

Therefore, a dynamic and effective interaction between deaf and hard of hearing students and their peers and instructors is considered necessary, which will take into account their needs, in order to increase their level of satisfaction with distance learning and reduce the dropout rates (Kounatidou \& Mavroeides, 2019).

This interaction can be achieved by using social media; nowadays everyone uses social media to interact with friends, family, fellow pupils and peers. Communication via social media may come with some challenges and be impersonal, as is the case with distance learning, but it can contribute to enhancing formal and informal learning (Vlachopanou \& Papadakis, 2019). Social media give learners more control over their learning. A positive outcome is the fact that the feelings of loneliness and isolation are reduced while the support provided to pupils/university students by teachers/lecturers is increased, because it becomes possible to use synergistic approaches that are beneficial to everyone (Toofaninejad et al., 2017; Vlachopanou \& Papadakis, 2019).

Proper preparation of teachers/lecturers and pupils/university students is also considered necessary when it comes to distance learning. The teaching staff in primary, 
secondary and higher education should be more knowledgeable, theoretically and practically, about the advancements in Information and Communication Technologies and how these could be adapted to their needs in order to take education a step further. With the appropriate resources, school/university environments can be shaped and adapted according to the needs of heterogeneity, based on the principles of inclusive education.

On the other hand, one very effective way to remove these important barriers is for teachers and lecturers to adopt Universal Design for Learning (UDL) principles in their teaching. However, many teachers and lecturers are aware that the UDL approach is still in its early phases in these educational settings and it is almost unused. Use of this approach could be one way to address these difficult situations in the era of COVID-19 and to develop learning materials and lessons and to increase the inclusiveness of "distance learning" (Petretto et al., 2020, p.1).

In addition, preschool and primary school teachers can also use Response Cards, which can be an important instructional tool in their teaching. According to Narayan, Heward and Gardner (1990), a Response Card is any object that all students in the class can lift at the same time in order to answer a question posed by the teacher. Response Cards can be whiteboards, standard cards or labels (e.g., plus or minus, true or false) that students raise at the same time to show their answers to the teacher's questions (Randolph, 2007). Such cards can be used in various lessons (mathematics, physics, chemistry, sociology, etc.), as they are a very important, extremely low cost tool (Berrong, Schuster, Morse, \& Collins, 2007; Bittinger, 2015; Christle \& Schuster, 2003; Clarke, Haydon, Bauer, \& Epperly, 2015; Didion, Toste, \& Wehby, 2018; Duchaine, Jolivette, Fredrick, \& Alberto, 2018; George, 2010; Randolph, 2007). A literature review (Horn, 2010) of six studies evaluated the use of Response Cards specifically for disabled students, and found that use of these cards is an effective strategy that increases the number of students' active responses and their commitment to instructional activities. Herring and Woolsey (2020) argue that due to their visual nature, Response Cards could be an effective strategy for general and special education teachers dealing with deaf and hard of hearing students.

Furthermore, in order to facilitate the distance education of deaf and hard of hearing students, teachers and lecturers could use one very important piece of software called Saba Centra. This software has proven to be a useful educational tool for deaf and hard of hearing students, due to its video projection feature. It can be a powerful and effective method for teaching both deaf and hard of hearing and hearing students (Slike, Berman, Kline, Rebilas \& Bosch, 2008).

More research is needed in order to more deeply understand the impact of this situation on the lives of these children and young adults. Such research should focus on the experiences of deaf and hard of hearing individuals, the experiences of teachers at all levels of education and the experiences of parents of deaf and hard of hearing children. Also, one very interesting topic that researchers could investigate is how the COVID-19 crisis affects the lives and work of deaf/ hard of hearing teachers. The questions that need 
to be asked during the research will open up a better, more in-depth study of the subject. Such research could help the Greek government to better understand the needs of these groups and to develop and apply better quality policies for them during this crisis or in any similar future crisis.

\section{Conclusion}

The times we live in require radical changes and genuine interest for these changes to be effective. To make this possible, strategies and methods should be adopted, which will be based on an inclusive educational model focusing on pupils/university students.

We could say that in these difficult times the philosophy of the "new capitalism" amplifies more his "neoliberal ideological orientations", which promote an "educational culture of standardisation" (Liasidou \& Symeou, 2016, p.13) that represents the ideology of homogeneity in education. Therefore, in such unprecedented conditions, the field of education needs creative people with a vision, who are able to introduce real changes in education, with more inclusive practices. Finally, the Greek Ministry of Education needs to put more measures in place in order to address the needs of these children and young adults. These measures should focus on accessibility at various levels because accessibility is very important for these individuals. Without it, no obstacle can be eliminated. These measures should cover the needs of both teachers/lecturers and students in order to promote the inclusion of the latter. For example, at preschool and primary education level, one additional measure that could be beneficial for both teachers and students is for the Greek government to make use of NSRF funds, hiring more teachers in preschool and primary inclusive education and creating smaller classes. Another important measure is for the Greek Ministry of Education to donate deaffriendly face masks to all teaching staff and students.

\section{Acknowledgments}

The authors gratefully acknowledge Mr George Egglezos, for his contribution and his comments on this article.

\section{Disclosure statement}

No potential conflict of interest was reported by the authors.

\section{About the Authors}

Constantinos N. Mantzikos is a special education teacher. He has received a B.Ed on special education from the Department of Special Education at the University of Thessaly (Volos, Greece). He has several years of teaching experience in children with disabilities and/or special educational needs in Greek public schools. Additionally, he has also published many research articles in the field of educational psychology and special education. His research interests mainly focus on developmental disabilities, deaf studies, deaf and inclusion, disability studies, inclusive education, special education, 
differentiated instruction, European and non-European education policies, home-school collaboration, disability models. ORCID: http://orcid.org/0000-0003-1698-5767

Christina S. Lappa is an Academic Tutor-Advisor of Special Education at the Hellenic Open University (Patras, Greece) and at the University of Thessaly (Department of Special Education) (Volos, Greece). She has a Master of Science in School Psychology from L'Aquila University (Italy) and she has received her Ph.D. in Special Education from the Department of Special Education at the University of Thessaly (Volos, Greece). Furthermore, she has done her Post-Doctoral research on special education at the University of Thessaly. She has teaching experience in children and adults with disabilities and/or special educational needs in Greek public schools and universities. She has also published many research articles in the field of educational psychology and special education. Her research interests mainly focus on developmental disabilities, deaf education, deaf and inclusion, special education, inclusive education, disability models, European and non-European education policies, environmental education, differentiated instruction, applied behaviour analysis, social skills and conversational skills. ORCID: http://orcid.org/0000-0002-3960-2450

\section{References}

Ackah-Jnr, F. R. \& Danso, J. B. (2018). Examining the physical environment of Ghanaian inclusive schools: how accessible, suitable and appropriate is such environment for inclusive education? International Journal of Inclusive Education, 23(2), 188-208. https://doi.org/10.1080/13603116.2018.1427808

Ainscow, M. (2005). Developing inclusive education systems: what are the levers for change? Journal of Educational Change, 6(2), 109-124.

Alasim, K. \& Paul, P. V. (2018). Understanding factors that affect teachers' attitudes toward inclusion of students who are hard of hearing in Saudi Arabia. Deafness $\mathcal{E}$ Education International, 21(4), 210-226. https://doi.org/10.1080/14643154.2018.1489950

Angelides, P., Stylianou, T., \& Gibbs, P. (2006). Preparing teachers for inclusive education in Cyprus. Teaching and Teaching Education, 22(4), 513-522. https://doi.org/10.1016/j.tate.2005.11.013

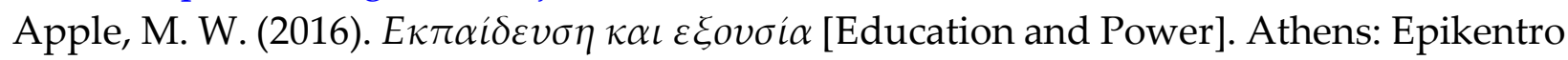
Publishers.

Barkas, L. A., Armstrong, P.-A., \& Bishop, G. (2020). Is inclusion still an illusion in higher education? Exploring the curriculum through the student voice. International Journal of Inclusive Education, 1-16. https://doi.org/10.1080/13603116.2020.1776777

Berrong, A. K., Schuster, J. W., Morse, T. E., \& Collins, B. C. (2007). The effects of response cards on active participation and social behavior of students with moderate and severe disabilities. Journal of Developmental and Physical Disabilities, 19, 187-199. 
Bittinger, D. L. (2015). The effects of Response Cards on 11th Grade Physics Achievement and off-task behaviors. Unpublished Master's Thesis. State University of New York, Fredonia, New York, USA.

CEDEFOP (2020, July 10). Greece: responses to the COVID-19 outbreak. https://cutt.ly/uatqvay

Christle, C. A., \& Schuster, J. W. (2003). The effects of using response cards on student participation, academic achievement, and on-task behavior during whole-class, math instruction. Journal of Behavioral Education, 12, 147-165.

Clarke, L. S., Haydon, T., Bauer, A., \& Epperly, A. C. (2015). Inclusion of Students with an Intellectual Disability in the General Education Classroom with the Use of Response Cards. Preventing School Failure: Alternative Education for Children and Youth, 60 (1), 35-42. https://doi.org/10.1080/1045988X.2014.966801

Didion, L. A., Toste, J. R., \& Wehby, J. H. (2018). Response Cards to Increase Engagement and Active Participation of Middle School Students with EBD. Remedial and Special Education, 41(2), 111-123. https://doi.org/10.1177/0741932518800807

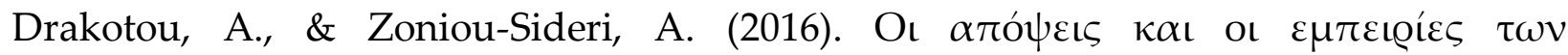

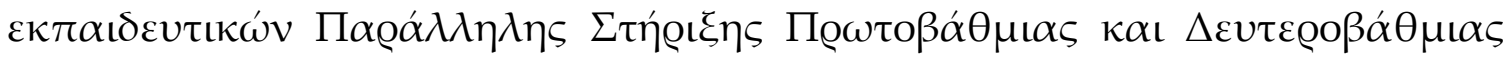

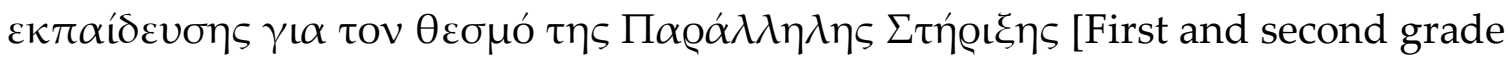
"support teachers" opinions and experiences regarding the institution of "support teacher"]. In: A. Zoniou-Sideri, E. Nteropoulou-Nterou, \& K. Papadopoulou.

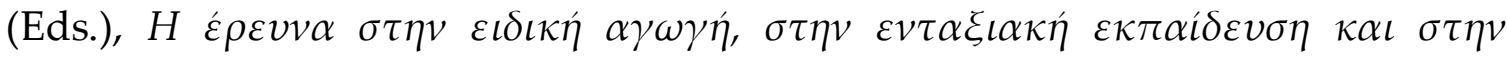
$\alpha v \alpha \pi \eta \rho i \alpha$ [Research in Special Education, inclusive education and disability] (Collective Volume E), (pp.11-27). Athens: Pedio Publications.

Drame, K. \& Kamphoff, K. (2014). Perceptions of Disability and Access to Inclusive Education in West Africa: A Comparative Case Study in Dakar, Senegal. International Journal of Special Education, 29(3), 69-81.

Duchaine, E. L., Jolivette, K., Fredrick, L. D., \& Alberto, P. A. (2018). Increase Engagement and Achievement with Response Cards: Science and Mathematics Inclusion Classes. Learning Disabilities: A Contemporary Journal 16(2), 157-176.

Edmunds, W. J. (2020). Finding a path to reopen schools during the COVID-19 pandemic. The Lancet Child $\mathcal{E}$ Adolescent Health. https://doi.org/10.1016/S2352-4642(20)30249$\underline{2}$

Ericks-Brophy, A. \& Whittingham, J. (2013). Teachers' Perceptions of the Inclusion of Children with Hearing Loss in General Education Settings. American Annals of the Deaf, 158(1), 63-97.

Fuller, M., Bradley, A. \& Healey, M. (2004). Incorporating disabled students within an inclusive higher education environment. Disability $\mathcal{E}$ Society, 19(5), 455-468. https://doi.org/10.1080/0968759042000235307

Fuller, M., Healey, M., Bradley, A. \& Hall, T. (2004). Barriers to learning: a systematic study of the experience of disabled students in one university. Studies in Higher Education, 29(3), 303-318. https://doi.org/10.1080/03075070410001682592 
George, C. L. (2010). Effects of response cards on performance and participation in social studies for middle school students with emotional and behavioral disorders. Behavioral Disorders, 35, 200-213. https://doi.org/10.1177/019874291003500302

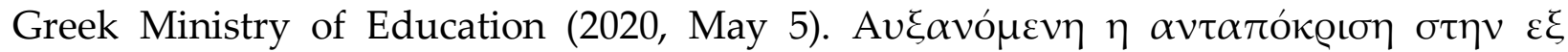
$\alpha \pi \sigma \sigma \tau \alpha \dot{\sigma} \sigma \varepsilon \omega \varsigma \varepsilon \kappa \pi \alpha i ́ \delta \varepsilon v \sigma \eta$ [Responding to distance education is increasing]. Minedu.gov.gr. https://cutt.ly/bodVigj

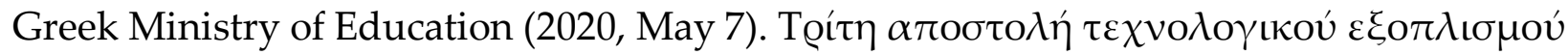

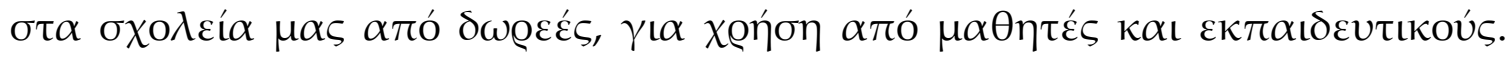

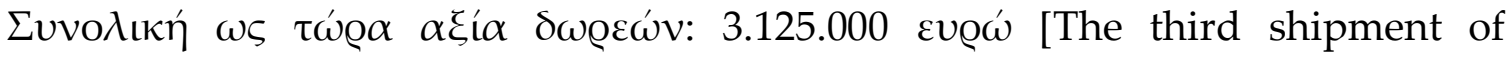
technological equipment to our schools from donations, for use by students and teachers. Total value of donations so far: 3,125,000 euros.]. Minedu.gov.gr. https://bit.ly/3hPukK4

Hankebo, T. (2018). Inclusive Education as an Approach to Reduce Inequitable Access to Education: Exploring the Practices of Jegnoch Metasebiya Primary School in Harar Town, Ethiopia. Journal of Teacher Education and Educators, 7(2), 123-138.

Herring, T. J., \& Woolsey, M. L. (2020). Three suggested teaching strategies for students who are deaf or hard of hearing. Support for Learning, 35(3), 346-358. https://doi.org/10.1111/1467-9604.12314

Hughes, C. E., \& Murawski, W. W. (2001). Lessons from Another Field: Applying Coteaching Strategies to Gifted Education. Gifted Child Quarterly, 45 (3), 195-204. https://doi.org/10.1177/001698620104500304

Humphrey, N., \& Lewis, S. (2008). 'Make me normal': the views and experiences of pupils on the autistic spectrum in mainstream secondary schools. Autism: An International Journal of Research and Practice, 12 (1), 23-47. https://doi.org/10.1177/1362361307085267

Kapasia, N., Paul, P., Roy, A., Saha, J., Zaveri, A., Mallick, R., ... Chouhan, P. (2020). Impact of lockdown on learning status of undergraduate and postgraduate students during COVID-19 pandemic in West Bengal, India. Children and Youth Services Review, 116, 1-26. https://doi.org/10.1016/j.childyouth.2020.105194

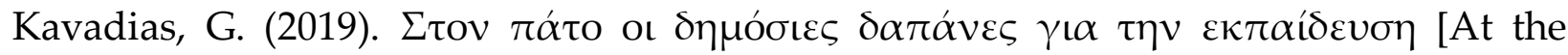
bottom are public spending on education]. Antitetradia tis Ekpaideysis, 126, 7.

Khalil, H. \& Ebner, M. (2014). MOOCs completion rates and possible methods to improve retention - a literature review. In J. Viteli \& M. Leikomaa (Eds.), Proceedings of Ed Media 2014-World Conference on Educational Media and Technology (pp. 1305-1313). Association for the Advancement of Computing in Education (AACE) https://cutt.ly/8omp9lH

Kiriungi, L., Mwitti, R. \& Mburugu, B. (2014). An Assessment of Public Primary School Teachers' Attitude towards Inclusion of Children with Hearing Impairment in Central Region of Kenya. International Journal of Education and Research, 2 (3), 1-10.

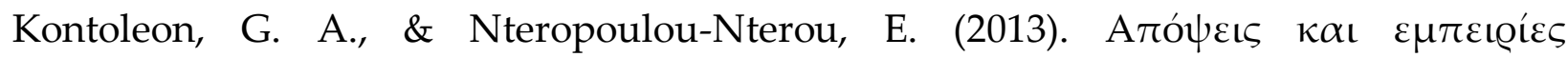

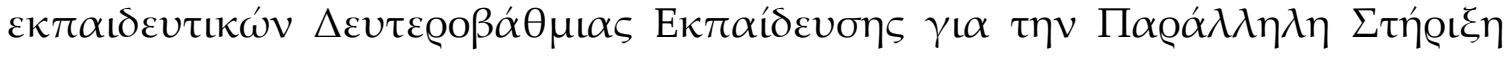

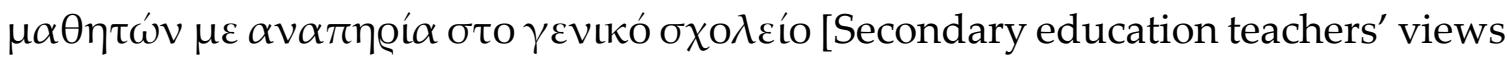


and experiences towards the role of support teachers of students with disabilities inside the regular classrooms in mainstream schools]. In: A. Zoniou-Sideri, E.

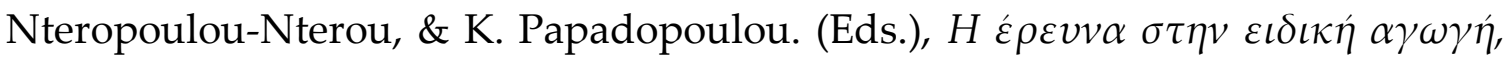
$\sigma \tau \eta v \varepsilon v \tau \alpha \xi \iota \alpha \kappa \eta \dot{~ \varepsilon \kappa \pi \alpha i \delta \varepsilon v \sigma \eta ~ \kappa \alpha \iota ~ \sigma \tau \eta v ~ \alpha v \alpha \pi \eta \rho i ́ \alpha ~[R e s e a r c h ~ i n ~ S p e c i a l ~ E d u c a t i o n, ~}$ inclusive education and disability] (Collective Volume C), (pp.11-34). Athens: Pedio Publications.

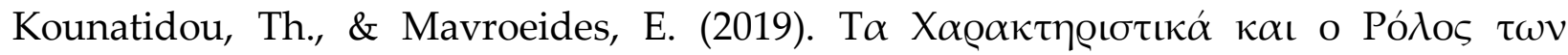

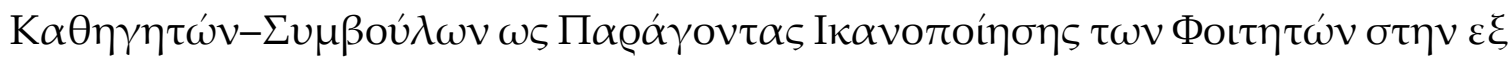

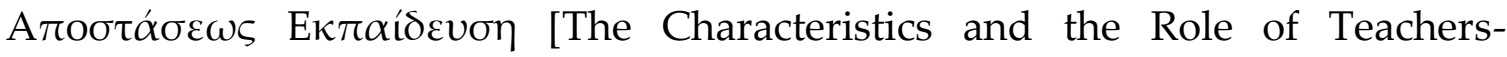
Counselors as a Student Satisfaction Factor in Distance Education]. Open Education: The Journal for Open and Distance Education and Educational Technology, 15(2), 7-23. https://doi.org/10.12681/jode.19590

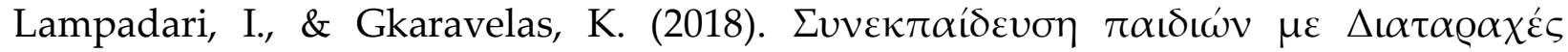

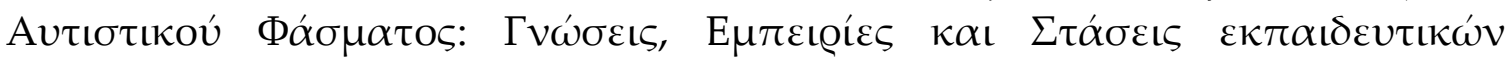

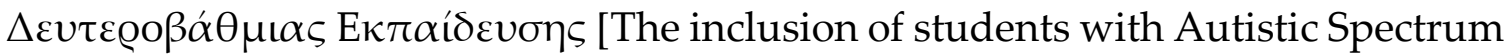
Disorder: Experience, knowledge, and attitudes of Secondary Education Teachers]. Theory and Research in the Sciences of Education, 29, 7-32.

Lampropoulou, V. \& Padeliadu, S. (1997). Teachers of the Deaf as Compared with Other Groups of Teachers: Attitudes toward People with Disabilities and Inclusion. American Annals of the Deaf, 142(1), 26-33.

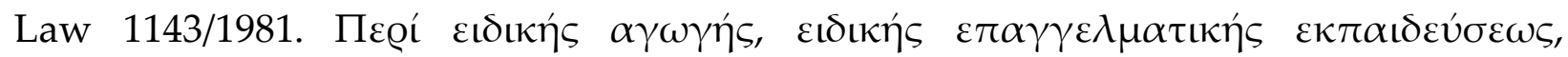

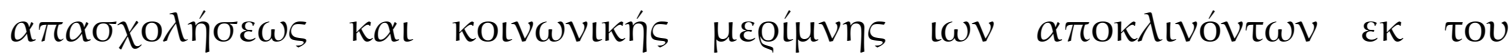

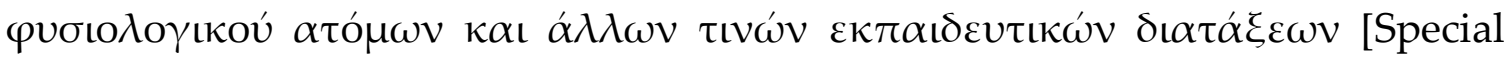
Education, Specialised Vocational Training, Employment and Social Care of diverging individuals from normalisation and other Educational Provisions]. FEK March 3, 1981, v. A', n. 80.

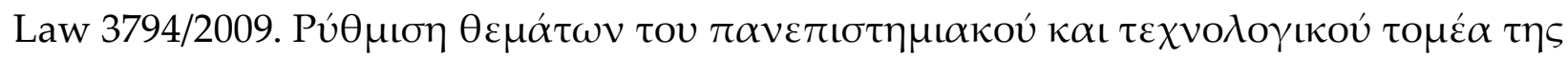

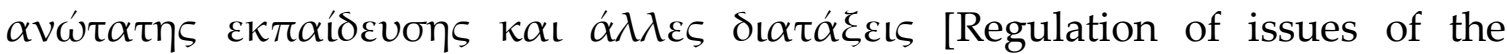
university and technological sector of higher education and other provisions]. FEK September 4, 2009, 156/A'.

Levinson, M., Cevik, M. \& Lipsitch, M. (2020). Reopening Primary Schools during the Pandemic. New England Journal of Medicine. https://www.nejm.org/doi/full/10.1056/NEJMms2024920

Liasidou, A. (2014). Critical disability studies and socially just change in higher education. British Journal of Special Education, 41(2), 120-135. https://doi.org/10.1111/1467-8578.12063

Liasidou, A., \& Symeou, L. (2016). Neoliberal versus social justice reforms in education policy and practice: discourses, politics and disability rights in education. Critical Studies in Education, 59(2), 149-166. http://dx.doi.org/10.1080/17508487.2016.1186102

Mapolisa, T. \& Tshabalala, T. (2013). The Impact of Inclusion of Children with Hearing Impairment into Regular Schools: A Case Study of Dakamela Primary School in 
Zimbabwe. International Journal of Asian Social Science, Asian Economic and Social Society, 3(7), 1500-1510.

Mavropalias, T., Alevriadou, A. \& Rachanioti, E. (2019). Parental perspectives on inclusive education for children with intellectual disabilities in Greece. International Journal of Developmental Disabilities, 19. https://doi.org/10.1080/20473869.2019.1675429

Moriña, A. \& Orozco, I. (2020). Spanish faculty members speak out: Barriers and aids for students with disabilities at university. Disability $\mathcal{E}$ Society, 1-20. https://doi.org/10.1080/09687599.2020.1723495

Moswela, E. \& Mukhopadhyay, S. (2011). Asking for too much? The voices of students with disabilities in Botswana. Disability $\mathcal{E}$ Society, 26(3), 307-319. https://doi.org/10.1080/09687599.2011.560414

Narayan J, Heward W.L, Gardner R., III. (1990). Using response cards to increase student participation in an elementary classroom. Journal of Applied Behavior Analysis, 23, 483-490. https://doi.org/10.1901/jaba.1990.23-483

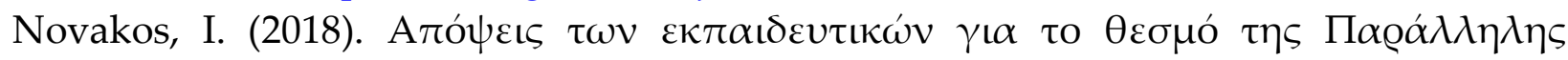
$\Sigma \tau \eta \dot{\varrho} \xi \eta \varsigma \sigma \tau \eta \nu$ E $\lambda \lambda \alpha \dot{\delta} \delta \alpha$ [The views of teachers about the institution of Parallel Support in Greece]. Theory and Research in the Sciences of Education, 26, 7-32.

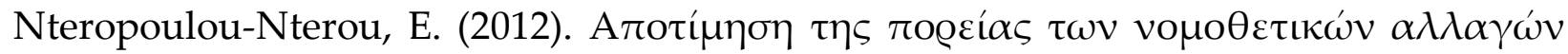

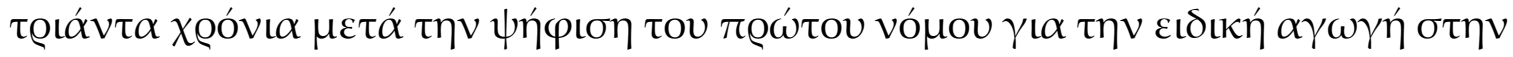
$\mathrm{E} \lambda \lambda \alpha \dot{\alpha} \delta \alpha$ [The evaluation of the course of legislative changes thirty years after the adoption of the first law on special education in Greece]. In: A. Zoniou-Sideri, E.

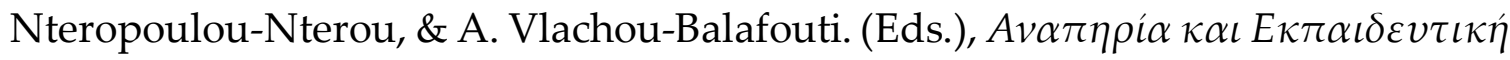

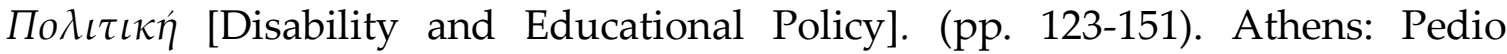
Publications.

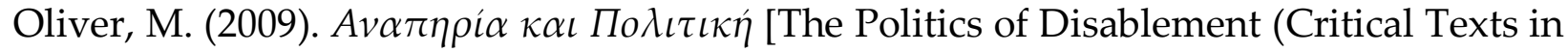
Social Work \& the Welfare State]. Athens: Epikentro Publishers.

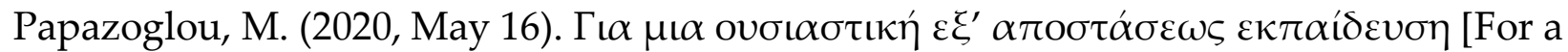
substantial distance education]. Kathimerini Journal. https://cutt.ly/DodBc6R

Parhoon, K., Movallali, G., Hassanzadeh, S. \& Moravej, M. (2014). Attitude of Regular and itinerant Teachers Towards the Inclusion of Hearing Impairment Children. Iranian Rehabilitation Journal, 12 (22), 22-28.

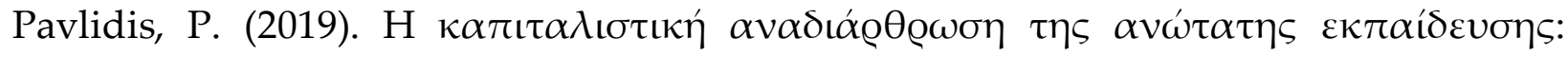

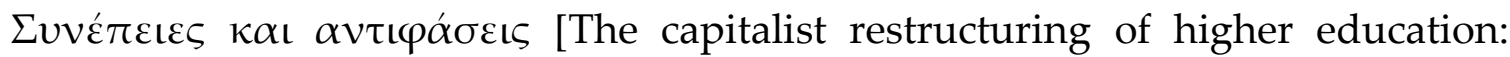
Consequences and contradictions]. Antitetradia tis ekpaideysis, 126, 8-10.

Petretto, D. R., Masala, I., \& Masala, C. (2020). Special Educational Needs, Distance Learning, Inclusion and COVID-19. Education Sciences, 10(6), 154-155. https://doi.org/10.3390/educsci10060154.

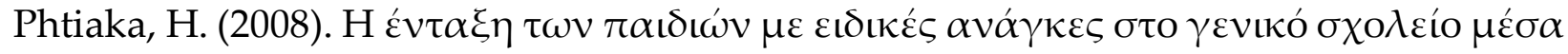

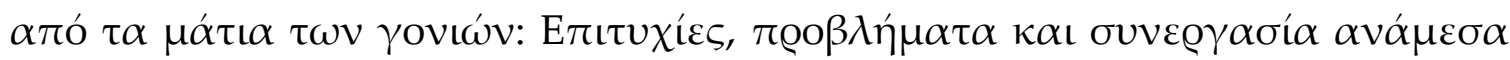

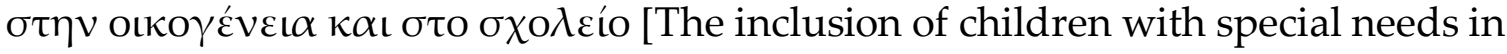
general education schools through the eyes of parents: Successes, problems and 


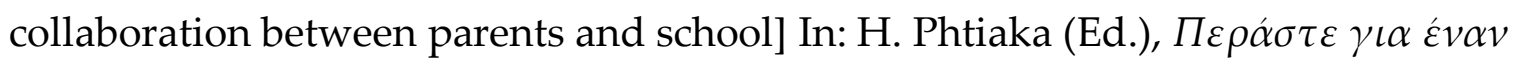

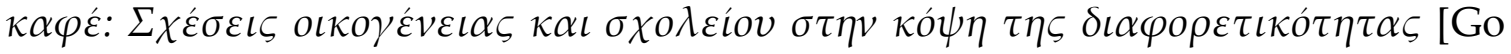
for a coffee: Family and school relationships at the edge of diversity] (pp.123-167). Athens: Taxideytis Publications.

Randolph, J. (2007). Meta-analysis of the research on response cards: Effects on test achievement, quiz achievement, participation, and off-task behavior. Journal of Positive Behavior Interventions, 9, 113-128. https://doi.org/10.1177/10983007070090020201.

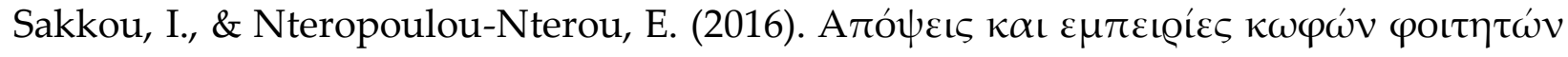

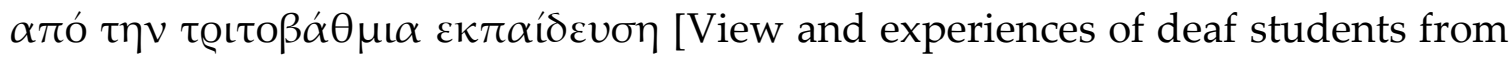
higher education] In: A. Zoniou-Sideri, E. Deropoulou-Derou, \& K. Papadopoulou

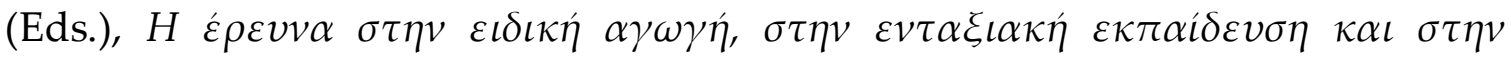
$\alpha v \alpha \pi \eta \rho i \alpha$ [Research in Special Education, inclusive education and disability] (pp. 95-113) (Collective Volum E). Athens: Pedio publications.

Sari, H. (2007). The Influence of an In-service Teacher Training (INSET) Programme on Attitudes towards Inclusion by Regular Classroom Teachers Who Teach Deaf Students in Primary Schools in Turkey. Deafness \& Education International, 9(3), 131-146. https://doi.org/10.1179/146431507790559996

Sarris, D., Riga, P., \& Zaragas, H. (2018). School teachers' attitudes toward inclusive education in Greece. European Journal of Special Education Research, 3 (3), 182-194. http://dx.doi.org/10.46827/ejse.v0i0.1668

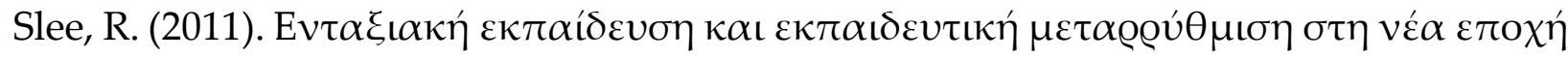
[Inclusive education and education reform in the new era]. In: A. Zoniou-Sideri, \&

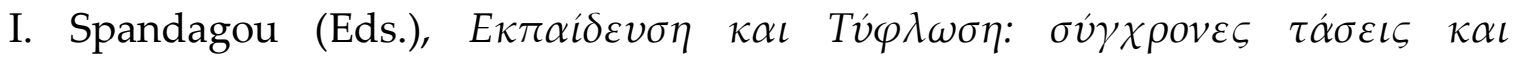

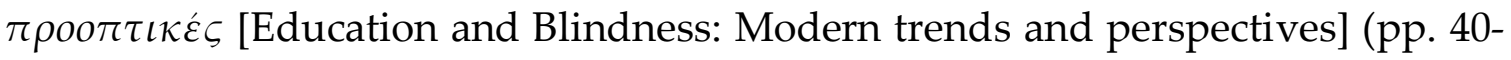
56). Athens: Pedio Publications.

Slike, S.B., Berman, P.D., Kline, T., Rebilas, K. \& Bosch, E. (2008). Providing Online Course Opportunities for Learners Who are Deaf, Hard of Hearing, or Hearing. American Annals of the Deaf, 153(3), 304-308.

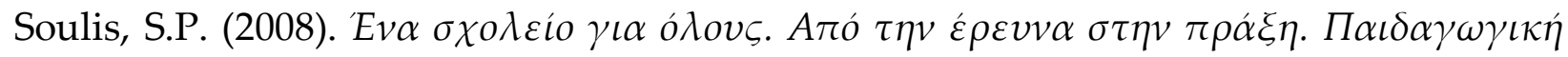
$\tau \eta \varsigma \varepsilon v \tau \tau \xi \eta \varsigma$ [A school for all. From research to practice. The pedagogy of integration] (Volume B). Athens: Gutenberg Publishers.

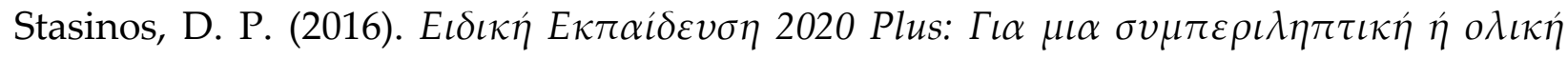

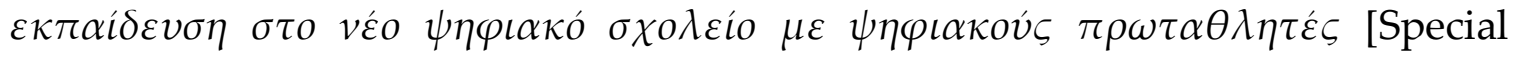
Education 2020 plus: For inclusive or total education in the new digital school with digital champions]. Athens: Papazisis Publications.

Takala, M., Pirttimaa, R., \& Törmänen, M. (2009). Inclusive special education: the role of special education teachers in Finland. British Journal of Special Education, 36 (3), 162172. https://doi.org/10.1111/j.1467-8578.2009.00432.x.

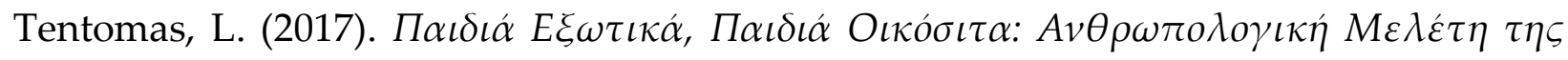

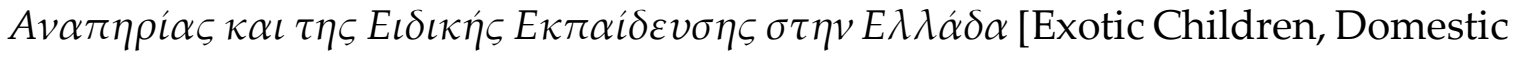


Children: Anthropological Study of Disability and Special Education in Greece]. Athens: Redmarks Publications.

Toofaninejad, E., Zaraii Zavaraki, E., Dawson, S., Poquet, O., \& Sharifi Daramadi, P. (2017). Social media use for deaf and hard of hearing students in educational settings: a systematic review of literature. Deafness $\mathcal{E}$ Education International, 19(34), 144-161. https://doi.org/10.1080/14643154.2017.1411874.

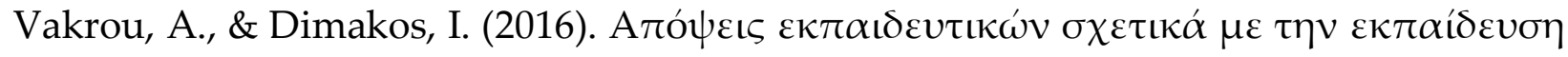

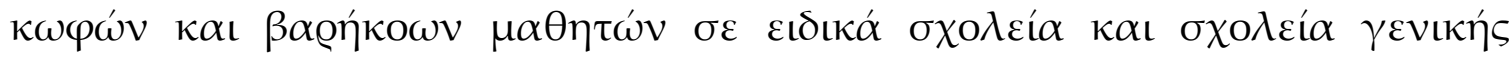
$\varepsilon \kappa \pi \alpha$ í $\varepsilon v \sigma \eta \varsigma$ [Views of teachers about the education of deaf and hard of hearing students in special schools and general education schools]. Pedagogikos Logos, 1, 3354.

Viner, R. M., Russell, S. J., Croker, H., Packer, J., Ward, J., Stansfield, C., ... Booy, R. (2020). School closure and management practices during coronavirus outbreaks including COVID-19: a rapid systematic review. The Lancet Child \& Adolescent Health, 4(5), 397-404. https://doi.org/10.1016/S2352-4642(20)30095-X.

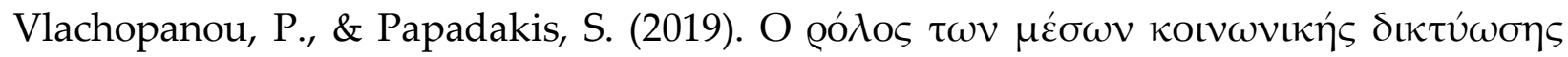

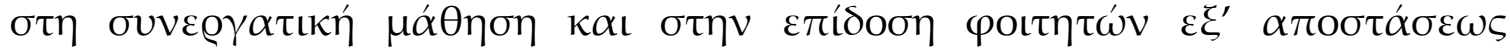
$\varepsilon \kappa \pi \alpha$ í $\varepsilon v \sigma \eta \varsigma$ [The role of social media in collaborative learning and the performance of distance learning students]. Open Education: The Journal for Open and Distance Education and Educational Technology, 15(2), 124-143. https://doi.org/10.12681/jode.14897.

Vlachou, A. \& Papananou, I. (2018). Experiences and Perspectives of Greek Higher Education Students with Disabilities. Educational Research, 60(2), 206-221. https://doi.org/10.1080/00131881.2018.1453752.

Vlachou, A. \& Papananou, P. (2015). Disabled students' narratives about their schooling $\begin{array}{lllll}\text { experiences. } & \text { Disability } & \mathcal{E} & \text { Society, } & 30(1),\end{array}$ https://doi.org/10.1080/09687599.2014.982787. 
Creative Commons licensing terms

Authors will retain the copyright of their published articles agreeing that a Creative Commons Attribution 4.0 International License (CC BY 4.0) terms will be applied to their work. Under the terms of this license, no permission is required from the author(s) or publisher for members of the community to copy, distribute, transmit or adapt the article content, providing a proper, prominent and unambiguous attribution to the authors in a manner that makes clear that the materials are being reused under permission of a Creative Commons License. Views, opinions and conclusions expressed in this research article are views, opinions and conclusions of the author(s). Open Access Publishing Group and European Journal of Special Education Research shall not be responsible or answerable for any loss, damage or liability caused in relation to/arising out of conflict of interests, copyright violations and inappropriate or inaccurate use of any kind content related or integrated on the research work. All the published works are meeting the Open Access Publishing requirements and can be freely accessed, shared, modified, distributed and used in educational, commercial and non-commercial purposes under a Creative Commons Attribution 4.0 International License (CC BY 4.0). 